Susanne Marten-Finnis

\title{
6 Spaces of Otherness and Desire. Ballets Russes-Artist-Animators-Ethnographic Enquiry
}

\subsection{Russian Modernism in Paris}

In 1910, a small group of exceedingly clever and progressive Russians arrived in Paris to challenge conventional art forms. These included the Ballets Russes impresario Sergei Diaghilev, whose troupe revolutionized the nature of the ballet; the dancer and choreographer Vaclav Nijinsky; the scenic artist Léon Bakst, whose décor changed Paris haute couture and London savoir vivre; and the young Igor Stravinsky, whose music was already being described as marking a most iconic moment in European Modernism. No other group established the Russian presence in Western Europe so emphatically.

The previous year, 1909, had seen the Ballets Russes performance of the Polovtsian Dances from Prince Igor, which had the effect of whipping up the Parisians into a state of sheer hysteria. Never before had their senses indulged in such scintillating music, such barbaric hues, and such rebellious gestures; never before was sown the germ of destruction, the spirit of unrest, or the embodiment of lawlessness (Woodcock, 2009, p. 56). No one in the West had seen men dancing like this. The imagined warrior-dancers from the Asian steppes and the tent-and-tribe approach of the ballet's decorator, Nicholas Roerich, fuelled the audiences' fantasies of Russia as a country that was inhabited by barbaric tribes with an innate passion for dancing.

During the years to come, this perception was consolidated by the physical representations of the Oriental Other, as displayed in the so-called Oriental Ballets staged between 1909 and 1912, for which Léon Bakst created the costumes and decoration. These Ballets established in the West a strong association of Russia with the cosmopolitan cities of her Asiatic periphery, rather than the orientation towards European values that had been broadcast by Tsar Peter I. The motivation for such self-presentation has been attributed to the impresario Sergei Diaghilev, who maintained that Western adulation of oriental exoticism on stage was easier to translate into money than Russian folklore.

Diaghilev's argument may have satisfied contemporary journalistic curiosity. But can it stand up as a complete explanation for the correspondence between Ballets Russes' corporeal characters and scenic display, and Western perceptions of Russia?

This article will challenge the view established among scholars and cultural ambassadors that Diaghilev's decision to flag Russia's Oriental Other was a mere PR act aimed at raising funds abroad for his theatrical venture. Departing from Russia's spectacular appearance on the Western stage in 1909, and from both a historical and a 
geographical perspective, it will trace an alternative path of Russian self-presentation and self-identification back to the realms of the ancient Silk Route, to classical Byzantium, and the more recent Russian annexation of Turkestan during the 1860s.

It will deconstruct the symbolic practices displayed by the dancers and decorators of the Ballets Russes and relate them to the transfer of knowledge initiated by Russian scholars, especially ethnographers, in the last third of the nineteenth century, between Russia's Christian-dominated centre in Europe and the recently acquired Muslim lands of her oriental periphery in Asia.

The body of knowledge that Russian Orientalist scholars mined from mapping this periphery in their ethnographic enquiry was largely ignored by Tsarist politicians. Instead, it led to a remarkable artistic upsurge during the Russian Silver Age, 1898-1914, when the Oriental theme came to permeate both the decorative and the performing arts. The strong responses that this theme elicited provided more than a momentary refuge from everyday life. Rather, as it will be argued here, it served various groups of artists as a platform abroad to rehearse a revamped identity, in which the unconditional pre-eminence of European culture broadcast two hundred years before by Tsar Peter I became increasingly challenged by Russia's Asiatic counterparts.

Now, Foucault classified as "counter-spaces" those spaces which lie outside the ordinary, promising liberation and illuminating a passage for our imagination (Foucault, 1986, as cited in Johnson, 2006). They contest the familiar spaces, and entry to them, Foucault maintained, is never straightforward. These counter-spaces will be discussed in the last part of this chapter ("Open Sesame"-The Transcultural Perspective of Russian Ethnographic Enquiry) in light of Foucault's (1986) “Theory of Other Spaces". The advantage of such an approach is evident for two reasons: firstly, it reveals the novel research methods of Russian Orientalist scholars, especially ethnographers, and their transcultural perspective that enabled them to unlock and access these counter-spaces. Secondly, it opens up a more differentiated perspective on the view expressed by Edward Said (1978) that knowledge has been used to subjugate the Other, together with his claim that Britain and France were the pioneering nations to launch Orientalist scholarship (pp. 1, 4-9).

\subsection{Russia on Display: Symbolism and the World of Art Group}

The symbolist approach that the Ballets Russes dancers and decorators displayed on the Paris stage originated from the Mir Iskusstva (World of Art) group. This group had grown out of a circle of friends around the duo of Sergei Diaghilev and Léon Bakst, who met regularly in 1890 (Kennedy, 1977, pp. 340-341). Among them were Alexandre Benois, Dmitri Filosofov, Ivan Bilibin, Nicholas Roerich, and others. Connected by a mutual interest in the arts and a passionate love of music, theatre, opera and ballet, the World of Art members launched their own magazine in 1899, in which they assailed the low artistic standards of the obsolescent Peredvizhniki (Wanderers) 
School, and promoted artistic individualism and other principles of Symbolism and Art Nouveau. In contrast with Realism, which stressed the relevance of an artefact to its social and political environment, Symbolism, prevailing during the 1890s until about 1910, provided an escape from everyday reality. It was concerned with the evocation of mood and subjective vision and used the intrinsic elements of painting, such as colour, line and light, as well as fabrics, for highly emotional and psychologically nuanced expression.

The group advocated an integrative approach to art and, like other Symbolists, worshipped Wagner's concept of a Gesamtkunstwerk in the sense of a total work of art, thereby referring to a theatrical performance in which all its constituent parts-music, singing, acting and scenery-were merged together into a perfect unity (Bridgman, 1989). Specifically, they absorbed the idea of music as a determining element that dictated gesture and action on the stage, thereby evoking an emotional response. ${ }^{129}$

The Parisians were among the first to discover this new form of integrated art, and although the dancers and decorators of the Ballets Russes had pretended to learn from the people in Western Europe, it turned out that they actually became their teachers. Hence, the World of Art group's contribution to European Modernism lay not only in the renewal of bodily display in the classical ballet, thanks to the choreography of Michel Fokine, Vaclav Nijinsky, Leonide Massine, Bronislava Nijinskaia and George Balanchine, as well as the modernist music of Russian composers such as Igor Stravinsky and Alexander Borodin, but also in the important changes they brought across in the early 1910s. These changes had to do with costume design, stage décor and fashion. Diaghilev (1910) confirmed that

in our classical ballet, dancing is only one of the show's components. The evolution that we initiated in classical ballet deals maybe less with the specific domain of dancing than with the other aspects of the show. It deals primarily with sets and costumes. (Diaghilev, 1910)

Perhaps the best example to demonstrate the Ballets Russes' influence on Paris couture is the set design of Scheherazade, with its main colour scheme being a combination of peacock green and spicy blue, as applied in Mughal-style paintings. It inspired the jeweller Cartier to set emeralds and sapphires together for the first time since the Mughal emperors (Buckle, 1979, p. 171).

While the Parisians of the day were inspired by the variety of costumes, their London counterparts were conversely fascinated by the stage sets, especially the space management and lighting effects implemented by Diaghilev's designers, and most of all by the "Asiatic barbarism of colours" (Komissarzhevskii, 1922, p. 11), which they proceeded to introduce into their homes. The various examples of exoticism proclaimed by the Ballets Russes had an impact on domestic interiors of upper

129 On the concept and programme of the magazine Mir Iskusstva, see Shestakov (1998). 
middle-class London, and were later claimed by the Art Deco of the 1920s. The British art critic and stage designer Osbert Lancaster confirmed that "the pale pastel shaded drawing-rooms that had reigned supreme on the walls of Mayfair for almost two decades were replaced by a riot of barbaric hues - jade, green, purple, every variety of crimson and scarlet, and above all, orange" (Lancaster, 1948, p. 58).

The Miriskussniki looked backward rather than forward, although their reveries were not confined to any historical epoch. Apart from Egypt, Greece, and Versailles, they cultivated a strong interest in the Middle Ages and what they perceived as primitive cultures (Bowlt, 1998, pp. 25-26), as is demonstrated by their deep reverence for Mikhail Vrubel, whose art they regarded as the incarnation of an archaic, barbaric force, a world of ancient myth and elemental unity (Bowlt, 1998, pp. 25-26). Another feature of their artistic aesthetic was their Orientalism; for them, the East represented a beautiful daydream, which they contrasted with the mundane prose of life (Kiselev, 1989).

Yet, the idea of Russia looking to the East, rather than to the West, for self-understanding was much older than this. For a start, it had been suggested by Russia's bicontinental geography bridging Europe and Asia. The central element of this understanding was the notion of soil. As cartographic accuracy improved, more and more interpretations of geographical space were articulated in Russia. Among the variety of contrasting geopolitical self-images that Russia invented for herself as a particular geographical entity stretching between Asia and Europe, the notion of soil retained its importance. This stood in contrast with Europe, whose geographical realm since the fourteenth century was increasingly identified with the spirituality of Christendom, and a civilization and an ideology that claimed cultural and political exclusiveness, and, ultimately, superiority (Bassin, 1991).

Russian Orientalism (Schimmelpenninck Van Der Oye, 2010) had thus been prevalent within Russian thought for centuries, until the reign of Tsar Peter I saw the emergence of two rather contradictory viewpoints on Russia's relationship with both Asia and Europe. On the one hand, Peter acknowledged an orientation towards European values and the unconditional pre-eminence of European civilization. On the other hand, the expeditions he sent out to southern Siberia in order to explore the area in search of natural resources and new trade routes unearthed the existence of the Scythians, a nomadic people who populated the grassy steppes of Eurasia over 2,500 years ago. The discovery of their lifestyle in the 1720s, and the creation of more accurate maps, led to greater interest among scholars in the geography and history of these peoples populating the Eurasian plain, and subsequently led to the establishment of a new framework for exploring self-identity that negotiated both European and Asian civilizations.

Due to the exploration of the vast region stretching between northern China and the Black Sea, the identification with the Scythians and the idea of Russia-Eurasia as a third continent, entered into the picture Russian consciousness. As a result, modernizing Imperial Russia saw an increasing number of artists and intellectuals 
looking to Asia rather than Europe for both self-identification and inspiration. This led to a remarkable artistic upsurge during the Russian Silver Age, 1898-1914, when the oriental theme came to permeate both the decorative and the performing arts.

As a case in point one can look to the archaeological expeditions of Nicholas Roerich and his revelation of the Scythian style. Others refer to music and dance (Riasanovsky, 1967, pp. 44-45), as Russian composers were also looking to the East for spiritual inspiration. They identified a broad spectrum of shared patterns with Asiatic folk cultures and ethnographic affinities with Slav, Finno-Ugric, Tatar-Turkic and Mongolian elements (Riasanovsky, 1967, pp. 44-45). Rimsky-Korsakov, Borodin, Stravinsky and Balakirev all sourced their music from Russian folk songs picked up in the Caucasus region, utilizing the so-called five tone or Indo-Chinese scale that was characteristic of the music of the Finnic and Turkic tribes of the Volga basin, Mongol music and the music of Siam, Burma, and Indo-China. They were also inspired by an intonation, which mostly used (what they understood to be) minor scales and chords, in order to imitate moods that vary between grief, thoughtfulness and unexpected musical drama. The rhythm of the Russian songs tended to link Russia to Asia and to separate it from the other Slavs and the West. The same held to be true for dance. In contrast with the West, the Russian folk dance was not based on the dancing couple, a man and a woman holding each other and dancing together, but represented a variety of elements and a freedom of improvisation that was also found among the East Finns, the Mongols and Turkic and Caucasian peoples (Bassin, 1991).

With the Russian Seasons, these features travelled to Paris. While dancing and especially ballet-dancing, as an art form, had long enjoyed extensive royal patronage, Russia was bankrupt after their loss of a naval war with Japan (1904-1905). Diaghilev was thus on the lookout for new ways of attracting interest and support. Success did, however, not come immediately. When, in 1906, Diaghilev organized the first exhibition of Russian paintings at the Paris Salon d'automne, the response from the Parisian public was only lukewarm. The French people had no use for the paintings of Russian artists, who were attracted by the romanticism of the past. Diaghilev correctly gauged this situation and subsequently directed the activities of his contemporaries Bakst, Benois, Roerich, Golovin, Anisfeld, Goncharova and Larionov towards one goal-the theatre. This new departure was entirely successful. During the years to come Russian decorative art produced a revolution in stage settings (Levinson, 1924). According to the French art critic Léon Moussinac, the masterpieces and refinement of Russian stage art and décor (Lukomskii, 1922, pp. 3-4) animated "a marked influence on French decorative art that, languishing in its search for a new style, suddenly discovered the splendours of colour, and bore witness to an infatuation, which created the Ballet Russes fashion” (Moussinac, 1922, pp. 51-52).

Most spectacular and successful in this respect was the Orientalist theme that early twentieth-century Ballets Russes productions displayed when they stepped into the European arena. This involved the display of the body and a strict costume code, as it is exemplified on the couverture du programme of the 1910 Saisons Russes (Figure 


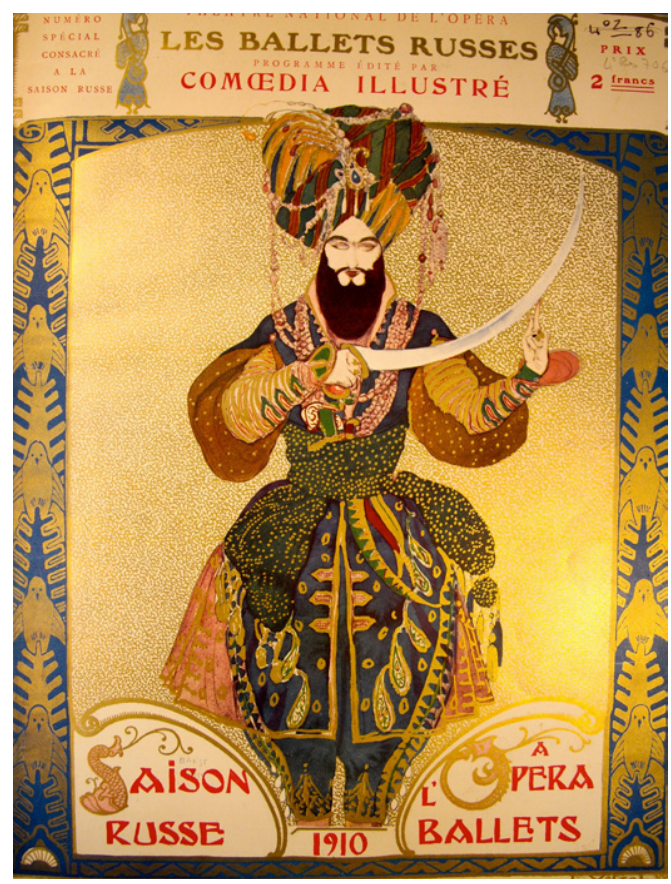

Figure 6.1: The display of a warrior wearing a turban and sabre evoked images of the Eurasian Steppe and the Mongolian advance into pre-modern Europe [Couverture du programme from Ballets Russes in 1910, Paris, Bibliothèque de l'Arsenal]

6.1) and, along with it, music, décor and colour rhythm. The display on the cover of the dancing sabre-man took place long before Aram Khatchaturian composed his Ballet Gayaneh in 1942, which included the famous Sabre Dance, with its middle section sourced from an Armenian folk song.

Ballets Russes spectators in Paris, it seemed, had expected a show that would reflect the European world of St. Petersburg (Woodcock, 2009, pp. 55-61) and the history of the Russian ballet. Instead, Russian composers, choreographers, dancers and decorators had merged their talents to display a completely different image of their country that revealed a strong identification with Russia's own Orient in Asia. The resulting spatial ambiguity held a huge attraction for the Parisians and will be discussed in the next section.

\subsection{Spatial Clarity and Spatial Ambiguity: The Case of "The Firebird"}

Ivan Bilibin's illustrations for the fairy-tale of The Firebird (Figures 6.3-6.7) and the sketches he made for the Golden Cockerel (Figure 6.2) pinpoint a clear separation between a familiar home and a threatening other space beyond. The latter shows a man wearing the traditional Russian-style kosovorotka after having travelled from 
a Russian homeland to a far-away land beyond in the Orient. This setting is indicated by the paisley-patterned tent as well as the cape and the headdress of a female Tamerlane.

The contrast between Russia's Christian West and the Muslim-dominated East appears even more accentuated in Bilibin's illustrations for the tale of The Firebird of 1906. In this work, he illustrates the Russian homeland with onion towers, and contrasts them with an architectural counter-space of mosques and minarets topped with the Red Crescent, and a city wall typical of the oriental city (Figures 6.3 and 6.4).

The same applies to the way that Bilibin portrayed people's faces and dress codes, as shown in Figures 6.5, 6.6, and 6.7 below. On the one hand, there are trusted figures with friendly faces wearing the traditional Russian clothing, laughing and dancing in a typically Russian environment. These he contrasts with people wearing turbans and sabres, caftans and burqas, behind which their faces are hidden. A peaceful space in the Russian woods, with Ivan's talisman, the grey wolf, is contrasted with a bellicose counter-space that shows Ivan on his knees before the sultan, his hands tied together behind his back. The sabres in the foreground and background convey the dramatic immediacy of a threatening counter-space in the Eurasian Steppe, that Russian readers would be able to associate with the Mongolian menace of pre-modern times. Only the bird is allowed to move freely between the two worlds and times: between a friendly home and a threatening land beyond, between modern and medieval times.

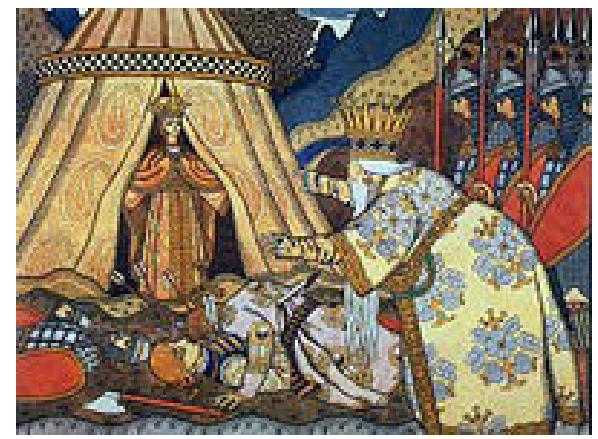

Figure 6.2: The tent

Note. The tent indicates the mobility of fast-moving, mounted, nomadic tribes who travelled lightly. Their tents are strongly related to the lightness of textiles rather than to the solidity of stone houses; the Bodom ${ }^{1}$ pattern points to an Oriental origin. The cape and headdress of the (female) Tamerlane are contrasted with the man dressed in a typical Russian-style kosovorotka.

1 In oriental design, Bodom or Kalamfur motifs refer to the almond or paprika pepper. Both were thought to afford protection from the dangers of the steppe due to their pepperiness and bitterness respectively. When the pattern became commercialized it travelled to Norwich for the factory production of shawls, and then further to Paisley, where the eponymous pattern was made (see Karpinski, 1963). 


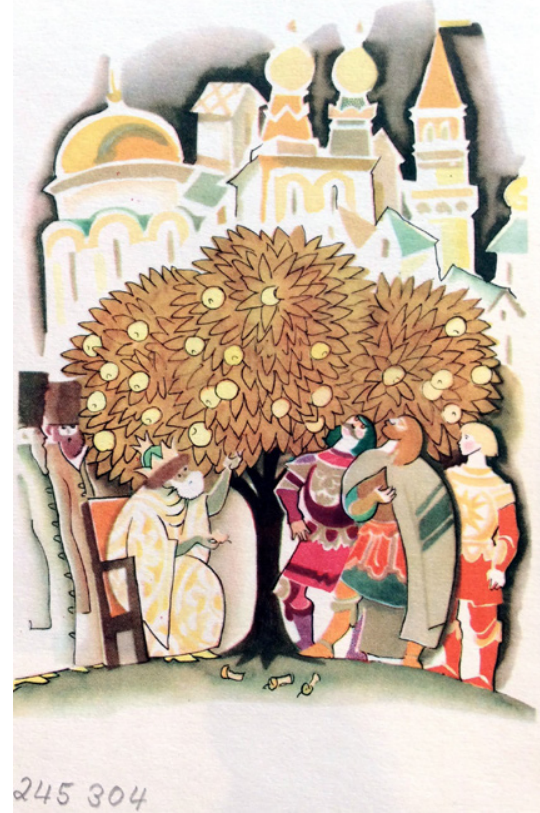

Figure 6.3: Architectural space in the Russian homeland

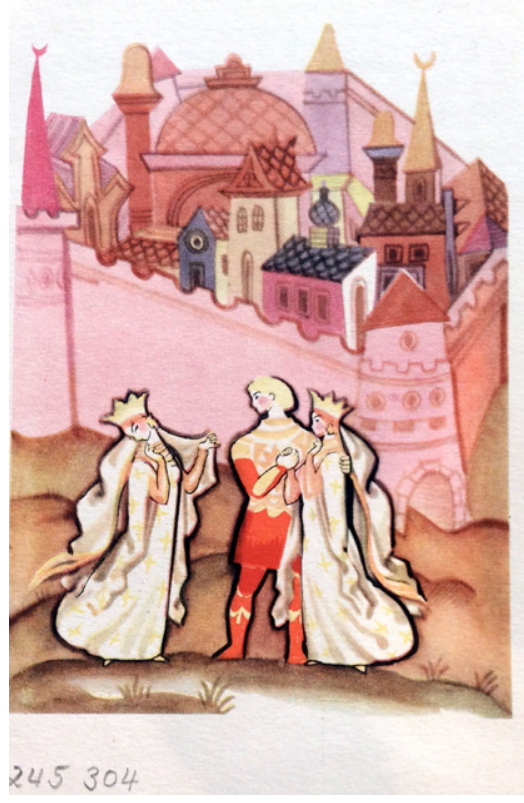

Figure 6.4: Architectural counter-space typical of the oriental city

Note. Skazka ob ivane-tsrevitche i o serom volke [Fairy-tale about Ivan Tsarevitch and the grey wolf. N. Gol'ts \& N. Shchepetov (Eds.) Moskva, 1969, without pagination].

However, the clear differentiation between the familiar and other spaces presented by Bilibin in 1906 is no longer prevalent in the costume and stage designs that Nicholas Roerich and Léon Bakst created for the Ballets Russes productions in Paris three to four years later. This is notably the case for the Polovtsian Dances and the Oriental Ballets (Cleopatra, Scheherazade, Thamar, Le Dieu Bleu), in which the boundaries between a Russian homeland and an Oriental counter-space become blurred, with no obvious marker of differentiation to be discovered between East and West. Noteworthy in this respect are Borodin's Polovtsian Dances, with their authentically ethnic Ikat-garments made in Uzbekistan (Figure 6.8), which Roerich had bought from Central Asian traders on the markets of St. Petersburg (Woodcock, 2010, p. 143).

Another example is Cleopatra, staged in 1909, with Bakst's display of the dancer Ida Rubinstein's exotic beauty against a colourful background of an Eastern setting, and her role as the Egyptian Queen, who gradually discarded her veils and gave herself up to the ecstasy of love before the eyes of the audience (Figure 6.9).

Cleopatra played on a European perception that essentially saw the ethnically, geographically, and intellectually varied Muslim world as monolithic and easy to define, specifically by way of representations that were heavily loaded with sexual connotations that gendered the East as feminine and the West as masculine (Nance, 


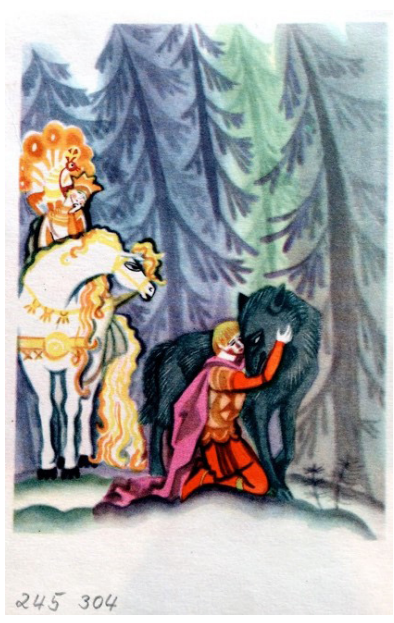

Figure 6.5: Peaceful Russian wood

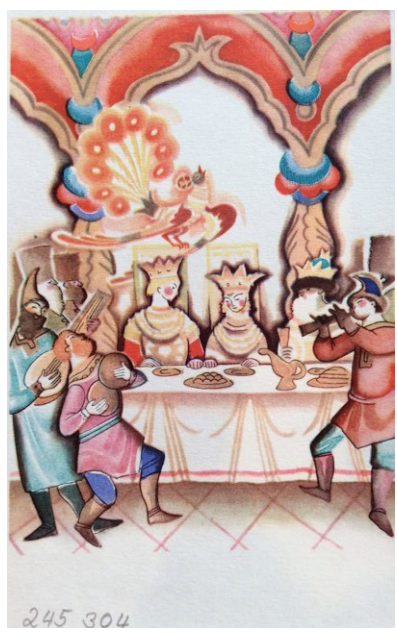

Figure 6.6: Homely Russian space

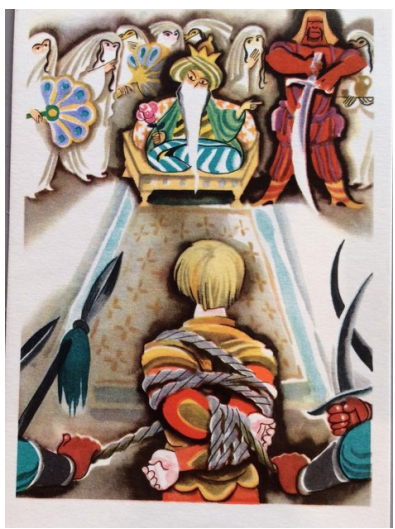

Figure 6.7: Threatening environment of the Other

Note. The figures clearly differentiate between a homely and a threatening environment of the Other. Skazka ob ivane-tsrevitche i o serom volke [Fairy-tale about Ivan Tsarevitch and the grey wolf. $\mathrm{N}$. Gol'ts and N. Shchepetov (Eds.) Moskva, 1969, without pagination]

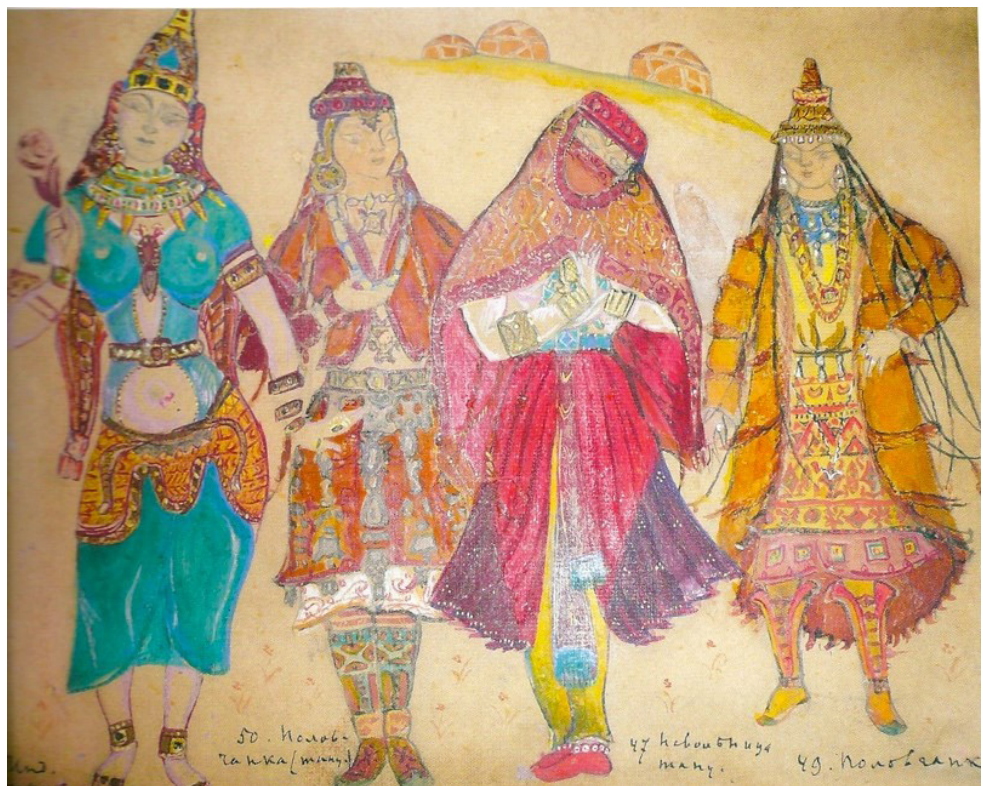

Figure 6.8: Costume designs by Nicholas Roerich for the dancers in Borodin's ballet Polovtsian Dances from Prince Igor

Note. Water colour on paper. State Pushkin Museum of Fine Arts, Moscow [Alston Purvis et al., The Ballet Russes and the Art of Design, Singapore, 2009, p. 157] 
2009 p. 3). The outstanding success of Cleopatra convinced both audiences and Diaghilev that the Ballets Russes should concentrate on sexy Orientalism, a total theatre of great music, superb dancing, thrilling design and simple themes of sex and violence.

Bakst's visual response to the Oriental theme made the display all the more exciting to the viewer, and it was in this light that Diaghilev asked him to create the costume and set design for Scheherazade which was performed a year later (Spencer, 1993). What could have been more obvious than exploring the roots of Oriental folk tales with their powerful images, and staging the myth of the storyteller-queen Scheherazade of One Thousand and One Nights (or The Arabian Nights, as the tales are known in the English-speaking world)?

Cairo forms the backdrop for most of the Arabian Nights; the core of the narrative was created here and reflects a social environment that is essentially cosmopolitan in nature. This cosmopolitanism-understood as a community linked by the here and now, rather than the age-old attachment to a place or tradition-held a great attraction for European audiences. They were fascinated by the situations of urban life as

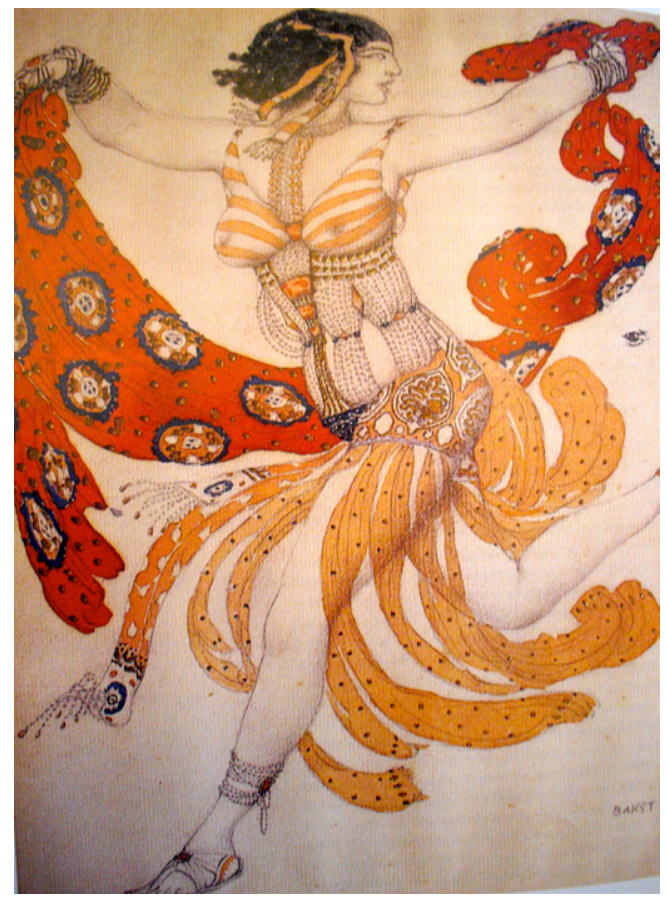

Figure 6.9: Bakst's design for Cleopatra

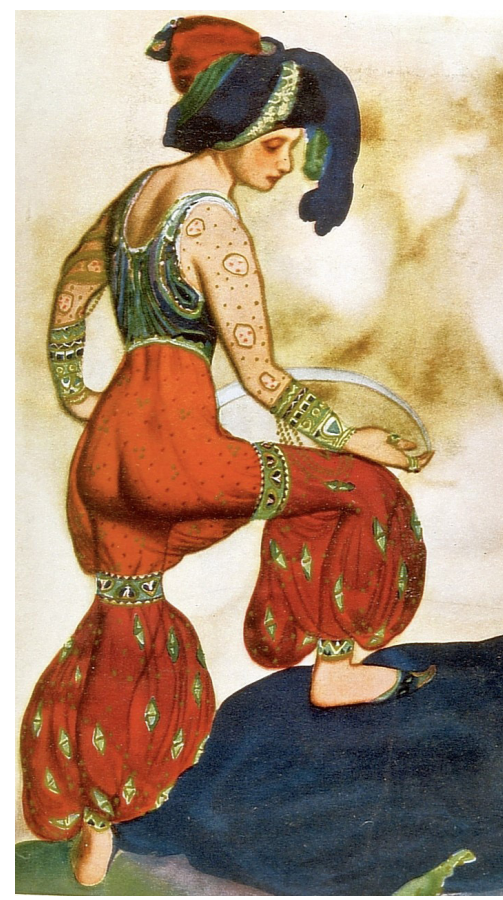

Figure 6.10: Bakst's design for the Red Sultan (Scheherazade)

Note. Alston Purvis et al., The Ballet Russes and the Art of Design, Singapore, 2009, pp. 62 and 166. 
they were displayed in the Arabian Nights, with their illustrations of intrigues, love stories and merchandise, and an Orient that promised sexual space, a voyage away from the restrictions of European Christianity and therein providing an escape from the dictates of bourgeois morality (Kabbini, 1986, p. 67). The tales provided for European readers unparalleled depictions of luxury, ease, and magical self-transformation in a robust language that matched the promise of consumer capitalism.

This was the context of Cleopatra and indeed of Scheherazade (Figure 6.10), which was also staged by Rubinstein. Furthermore, if Cleopatra had introduced Bakst's originality and splendour to the Parisians, then Scheherazade confirmed his uniqueness in their minds. Had such a riot of colour, such mountains of cushions, such enormous golden lamps and such a breaking of the Ten Commandments ever been seen as it was seen in Scheherazade? (Birnbaum, 1916) The ballet prompted critics to use words like "sensual", "erotic" and "sumptuous", conveying an image of desire that remained inseparably linked to the Ballets Russes performances staged before World War I.

In these performances, artistic licence took precedence over any semblance of chronological or cultural accuracy, and the Oriental space of the Ballets Russes referred to geographical areas in India and East of Suez (Schouvaloff, 1997, p. 39) (today generally referred to as "Levantine"), whose boundaries eventually reached Russia's own Orient. This is also the case in Thamar, the barbaric legend from the Caucasus that was based on Lermontov's ballad Thamara and Balakirev's symphonic poem to the music for which Fokine created a choreographic drama in one act. Bakst wrote the libretto and did the sets and costumes, which the Russian Seasons chronicler, Valerian Svietlov, found "imposing and, as always, extremely effective. ... But, for all that, I don't like them", he said, criticizing both their Orientalism as untypical of the harsh spirit of the Caucasus or of the even harsher Daryal ${ }^{130}$ and Bakst's treatment of Thamar in the following way: "Under the guise of a Georgian Queen one senses the image of a woman of the Art Nouveau age - devilishly beautiful, dangerous, seductive" (as cited in Diaghilev Festival, 2011, p. 14).

Bakst seemed to have created costumes that reveal and adorn the human body rather than cover it. They resembled the poses and silhouettes that Bakst had found on excavated Greek vase paintings and sculpture when he visited Crete in 1907 (Marten-Finnis, 2013). At this time, his contemporaries claimed that his attraction to antiquity became so all-absorbing that Bakst became obsessed with it "jusqu'au délire", as Alexandre Benois once put it (Auclair, 2009). Bakst's travels to Greece were essential in arousing his interest in archaic art. Upon his return, he points out that "the Greeks valued the beautiful, nude human body above all. ... For them”, he goes on, "heroes, gods, goddesses, and simple mortals were mere excuses to celebrate the uncovered body” (R. Johnson, 1990).

130 The Daryal is a 1200 meter-high pass in North Georgia, Central Greater Caucasus. 
This attitude remained prevalent even in Bakst's costume design for The Firebird. Although this ballet was originally purported to be a Russian neo-nationalist work of art (Benois, 1910), Bakst still sourced material for it from epics from the East. Staged only a month after the stunning success of Scheherazade, after Diaghilev had commissioned Bakst to redesign Golovin's original costumes for the key figures of The Firebird, the Tsarevna and Ivan Tsarevitch, they acquired elements that do not feature in the original Russian folk tale. At the time, Bakst's redesigned costumes made the French theatre critic Henri Ghéon gush with admiration: "How Russian that is!” (Ghéon, 1910). The "new” firebird (Figure 6.11) displayed some obviously incongruous details that Bakst sourced from Hindu folklore: the long golden plaits and a crown characteristic of Garuda, a divine bird in Hindu and Buddhist mythology, and the long fingernails which alluded to a dance from Siam that Bakst had watched, together with Fokine, and that was performed by the Royal Siamese Court in the main Imperial theatres of St. Petersburg in October 1900 (Misler, 1989).

In Bilibin's sketches, the Firebird belonged to a Russian homeland, and is imprisoned in a far-away land. The hero has to undertake a long and dangerous journey in

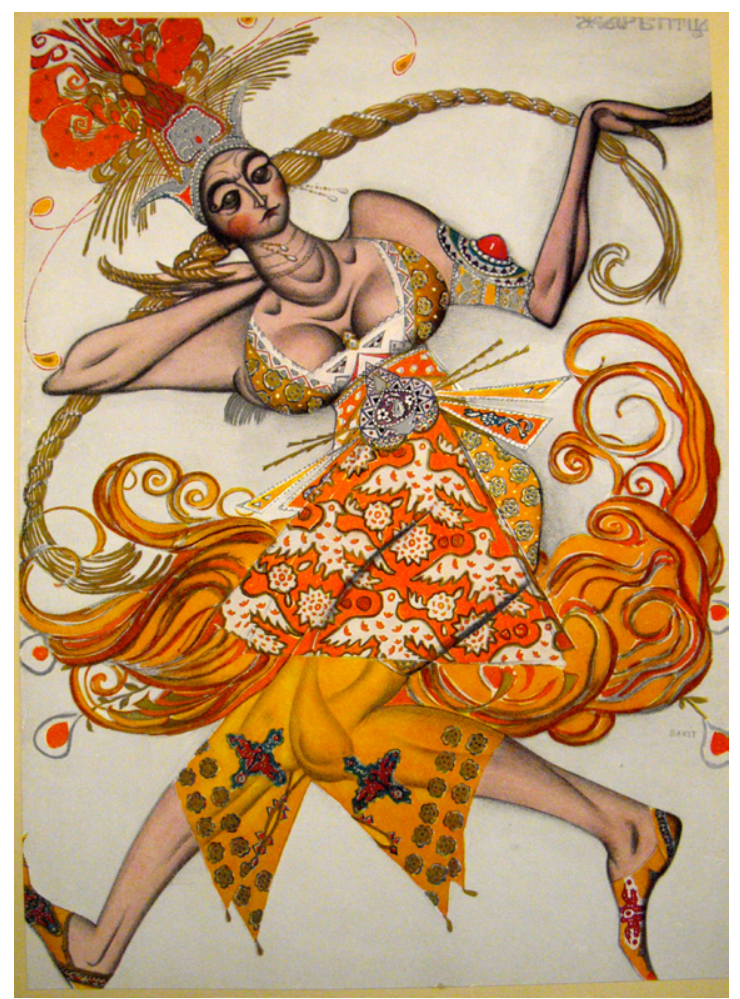

Figure 6.11: Bakst's costume design for The Firebird 
order to bring her back. On his way, he has to overcome a number of obstacles symbolizing borders. The origins of Bakst's Firebird, in contrast, lie in the East. As but one example of this, she flies in to the rescue in the opposite direction, from a land of the Other.

One reason for this change of perspective may have been the fact that Bilibin's sketches were aimed at the Russian reader, while Bakst's set designs were for the foreign spectator. Whereas in Russia The Firebird had enjoyed renewed celebrity through the late nineteenth and early twentieth centuries-as an embodiment of pure, heartless, unattainable beauty (Taruskin, 1996, p. 556) among Symbolists in general and particularly among World of Art members-it held an additional attraction for European audiences as a magical figure that could assist or impede the hero's quest. Moreover, it could help to unearth a treasure or liberate a captured maiden, as it was part of the typical supra-natural domain that formed a hallmark of the Arabian Nights, with their angels, demons and precious talismans who could utter magic formulas. Jinns, fairies, birds and sorcerers are all part of the strange world that exists in the Arabian Nights. As strangers to Western fantasies and repertoire, these creatures were very appealing to European audiences.

In order to incorporate them into the Ballets Russes' Firebird performance of 1910, a new plot had to be invented that differed from the original Russian tale. In that new plot, a young girl is kidnapped by a monster, a so-called Dev, and carried off into a faraway land to his castle on a high mountain, surrounded by thick walls without gates. There lies a beautiful enclosed garden within, as depicted on the cover of the Berlinbased Russian magazine Zhar Ptitsa [The Firebird] (Figure 6.12). The scenario that this exotic abduction evoked could also have been sourced from oriental epics: the narrative of a magic garden, the supra-natural creatures such as Kastcheï, the wicked ogre and his demons, and the Firebird as a good fairy, the former ogre and his demons are wicket, the Firebird is benevolent, but none of them is human (Evans, 1933, p. 9). This was the latter plot, for which Diaghilev had commissioned Igor Stravinsky to compose his suite. During the years to come, The Firebird became one of the most regularly performed ballets in the repertoire of the Ballets Russes, and it was praised for its marvellous synthesis of music, choreography and scenery.

This cover design rendered by Georg Schlicht points to further typical characteristics in a number of oriental tales (Usbekische Märchen, transl.1978, p. 76), depicting a counter-space, a world beyond, in which water and trees, greenery or simply the colour green play an important role (Taube, 1994, pp. 17-18).

Water and shade are also among further themes of the oriental garden. In contrast with European concepts of the garden's rich fertility, which are often fuelled by the ambition to master nature (the French approach) or to accommodate nature (the English approach), the oriental garden is associated with health, wealth and contemplation. Unlike English and French gardens, which are designed to be walked around in, it is a cool green place for rest and reflection. This is not surprising, since it constitutes a floral and faunal oasis in a hot and arid region, where human settlement 


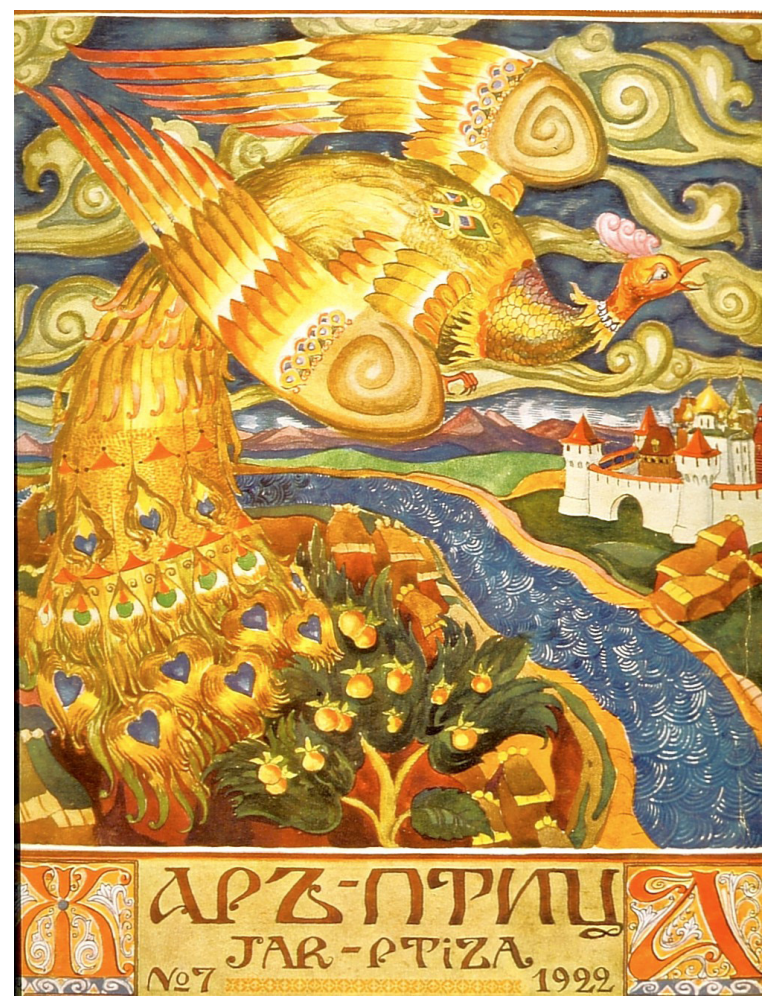

Figure 6.12: The Firebird displayed on the cover of the illustrated magazine Zhar Ptitsa $(7,1922)$ [Kunstbibliothek Berlin]

is usually more fragile than in the more favourable climatic conditions of Europe. In the oriental environment, plants implied water, and water meant healing, beauty and wealth. A garden could therefore be a protected, or even a heavily guarded place on or near mountains, a real treasure house. It was often surrounded by rivers or other obstacles such as massive walls, making access difficult (Usbekische Märchen, transl. 1978, p. 76).

Gracing the seventh issue of the international Russian magazine Zhar Ptitsa, which was issued between 1921 and 1926 in Russian, German and English (MartenFinnis, 2012, pp. 82-87) and distributed in Western Europe and the Americas, Schlicht's design revisited the Firebird production of 1910 and established among Western audiences an image that-unlike Bilibin's sketches-has little to do with the grey wolf and the Russian fairy-tale forest. Rather, Schlicht's Firebird flies in from an enchanted world in the East, and moves from ancient to modern times. This enchanted East is depicted as being full of a love of ornament, emphatic in colour and vigorous lines. The foreground shows a tree with stylized pomegranates, rather than apples, as they were illustrated by Bilibin in 1906 (see Figure 6.3). As a native fruit to the region between modern-day Iran, Pakistan, Afghanistan and northern India, the 
pomegranate is a symbol of well-being, fertility and abundance. Its symbolism has survived in the tapestries and rug making traditions of Central Asia. Schlicht's firebird also appears oversized. Her tail feathers display blue hearts that dissolve into bold and green motifs resembling the Mihrab ${ }^{131}$, thereby creating an ornament typical of Muslim architecture. The background is filled with light green clouds, whose abstract shapes resemble spirals associated with the sun and its yearly circle. Or, perhaps they revisit the apotropaic images of Bodom and Kalamfur (see footnote 2). The latter were also typical of oriental fabrics that had frequented Russian markets and often served to inspire Schlicht's work (Raev, 2018, p. 14). Hence, the eponymous name of the Berlin-based illustrated magazine was loaded with a double meaning: it was to remind German readers of the Firebird production performed by the Ballets Russes a decade earlier, and it pinpointed the thousands of immigrants from the East, who in the early 1920s made Berlin the first capital of Russian emigration. Rather than being despised by their German hosts as uninvited guests, the editor of Zhar Ptitsa might have fancied that he could see these emigrants illuminating their environment with a glow in the sense of "Light from the East"-ex oriente lux. At least, he indicated as much in his mission statement when he pointed out that:

our magazine's name is Zhar Ptitsa-what an unusual sounding name to a German ear! What does it mean? Shall we call it "Firebird” or even "Glowbird." Mind you, it is not the legendary phoenix from the German fairy tale, but rather its Russian sibling, lighting up with its glowing plumage a dark garden at midnight. On its wings, it carries the dream of nostalgia, joy and desire! $!^{132}$

Hence, while in the original Russian fairy-tale, the firebird was to guard the garden and the golden apple tree, the new firebird came from a country of pomegranates, and was to transform a far-away and threatening otherness-perhaps not quite into a space of desire-, but surely into a less dangerous place, one that was still beyond familiar boundaries but which was populated by trustworthy figures who ensure that good defeats evil. In this way, both Bakst's scenic decoration of 1910 and Schlicht's cover design for Zhar Ptitsa in 1922 celebrated a counter-space that may have been bewitching, but it was no longer presented as a space of the threatening Other.

131 The Mihrab imitated a niche in the wall of a mosque indicating the direction of Mecca, the direction that a person should face when praying.

132 “Zum Geleit [Introductory remarks].” Zhar Ptitsa no. 1 (August 1921) 1 (translation by S. MartenFinnis). 


\section{4 "Open Sesame"-The Transcultural Perspective of Russian Ethno- graphic Enquiry}

A very similar notion served Michel Foucault as a departure when he defined such other spaces as “counter-spaces"-or "heterotopias", derived from the Greek words heteros (other, another) and topos (place) (Foucault \& Miskowiec, 1986). According to Foucault, the oldest example of heterotopias that are capable of juxtaposing in a single real place several sites that are in themselves incompatible, is the sacred space of a Persian garden (Foucault \& Miskowiec, 1986, p. 25). Yet, Foucault did not borrow his concept from the Persian garden of oriental epics, but from hard medical science, where it refers to particular tissues which grow in places where they are not normally found, without, however, being diseased or threatening. Access to such counter-spaces, Foucault maintained, is never straightforward. While in Antiquity, it may have required the incantation of a magical formula to assist the hero's quest to gain entry to the Other's treasure house, in modern times their unlocking depended on a particular body of knowledge.

Foucault's conceptualization of these counter-spaces-or heterotopias-provoked a variety of responses across a number of academic disciplines, of which two stand out: firstly, that the reference to other spaces was seen as a stage in processes of modernization, and, secondly, that their representation may articulate a certain form of resistance (P. Johnson, 2006), rebellion or protest.

Both of these concomitant implications apply to the Ballets Russes' dancers, artists, musicians and choreographers. But we may ask how far outside the ordinary were the spatial qualities that they displayed in their productions when they were paying homage to an oriental aesthetic. To what extent were the claims of critics in Russia at Home justified in saying that the Ballets Russes' bodily and decorative display which they exported to the West was a false image of Russia as a semi-oriental nation? What was the nature of the discrepancy between Western perceptions of Russian dancers and decorators as Orientals, and their self-understanding as Europeans and Orientalists (Järvinen, 2008), in the sense of having learned about the Orient, rather than in being a part of it?

There are no straightforward answers to these questions. "The Parisians expected from us a certain amount of barbarianism", Diaghilev once said in an interview (as cited in Kahane \& Wild, 1922, p. 23). His self-imposed mission to delight western audiences with what he called "Russian art" was thus a question of economic capital, after the period when ballet-dancing no longer enjoyed tsarist patronage. Moreover, the oriental counter-space that Ballets Russes' productions displayed in the West had not just sprung from the mood of Diaghilev, Stravinsky or Bakst. Rather, they were part of a broader trend at the time in the performing and decorative arts across Europe. Yet, they were made more effective as they perfected the Wagnerian approach to a $\mathrm{Ge}$ samtkunstwerk, which implied the orchestrated sensual unity and the harmonization 
of the whole of bodily, scenic and musical display, in order to ravish the audience's eyes and ears simultaneously.

Such effects indeed reinforced Western stereotypes about a life of oriental ease, sensuality and despotism in an exotic East. Most importantly, however, it disclosed a familiarity with the East that revealed both authenticity and empathy. This attitude greatly differed from the civilizing mission which prevailed among Western audiences, with their body of knowledge about the Orient being derived from the two biggest colonial networks before the twentieth century. Hence, on the one hand, Ballets Russes productions endorsed an ideological position according to which Russia, like France or England, could be divided into two major components: a homeland or metropolis that belonged within European civilization, and a foreign, extra-European oriental periphery, whose chaos legitimized imperial authority and colonialism on a par with the Western powers. On the other hand, however, they disclosed an appreciation of the East that was worshipped, rather than despised or seen as being in need of improvement.

Now, it will be argued here that the reasons for these contrasting attitudes lie in the tools that the Ballets Russes' masters of enchantment had at their disposal, in order to open up the counter-space for their Western allies, and share with them the commodities of a treasure house that the latter were unaware of. But first, let us ask: What were their tools to gain entrance? How did they surmount the obstacles that might have hindered access? And, most importantly, where did they source the material culture for their display?

The answers to these questions lie in a combination of factors, of which the nature of access forms the key determinant. Hence, the first premise lay in the nature of Russia's bi-continental geography. In contrast with the maritime powers, Russian colonization of Asiatic territories took place over land; she did not possess far-flung overseas colonies, but nearby lands supporting a regulated interaction. These lands could be reached via the continental bridge, with no major bodies of water separating them. The ongoing transfer of people, ideas and material culture that this facilitated led, for instance, Uzbek silk merchants to markets in St. Petersburg and Russian government envoys to the areas of the ancient Silk Route. This interaction fuelled not only imperial expansion and artistic imagination, but also academic curiosity and a more systematic scholarly study of this Orient by means of ethnographic enquiry.

This enquiry had picked up speed following the Russian annexation of Turkestan in the 1860s. Tsarist politicians and scholars agreed that, as a civilized empire, Russia had a duty to investigate the complex and poorly understood customs of her subjects in order to understand their ways of life and beliefs, and to better integrate them into the nation as a whole. As a result, the role of ethnographers, linguists and geographers rose to prominence during the Era of the Great Reforms initiated under the reign of Tsar Alexander II (1855-1881), and ethnographic studies turned out to be the premier science in the Russian Modernization project of Turkestan (Tolz, 2011, p. 32). 
During the decades to come, the building of national communities occurred alongside the building of commercial relations with Central Asia. Economic ambitions had to give way to political concerns, of which the policy of citizen-building [гражданственность], i.e. the integration of Russians and non-Russians into a unified community of staunchly Russian citizens, was the principal element.

On this issue, a number of recommendations came from those who claimed to know the oriental borderlands best. Specifically, this meant academic Orientalists (Tolz, 2005), scholars studying the individual aspects of Orientalism together with its aesthetic assumptions, religious quests, intellectual priorities and political entanglements and their interrelationships. Themselves being influenced by the impact of nationalism on European scholarship, Russian Orientalists, in particular those of the Rozen School ${ }^{133}$, developed their own "national” approach to Oriental Studies, rather than reproducing the agenda of scholars in Western Europe, a fact which is all the more remarkable as none of the Rozen disciples was ethnically Russian. This ethnic background may have influenced their views on how to reconcile national aspirations and imperial governance within the Russian context. Moreover, it was perhaps this very condition that enabled them to work out an approach which allowed them to adopt and benefit from their transcultural perspective on the oriental heritage of Russia's new subjects' nationalities.

In particular, these scholars argued in favour of forging a multi-ethnic community (Jersild, 1997, p. 101; Yaroshevski, 1997, p. 61), based on the principles of civic nationalism in the sense of social integration and shared political values and responsibilities among Russians and non-Russians, despite their linguistic, cultural and religious otherness. Their path towards citizen-building foresaw cultural and political integration through educational projects shared with the subject nationalities in the eastern and southern borderlands, with the aim of fostering among the country's entire population a sense of community and unity. The educational projects that they put forward entailed a transfer of knowledge that was based on shared learning and teaching with the native population, with the help of textbooks specifically developed in their own languages about their local histories and heritage. This way, they claimed, the latter would first develop an ethno-cultural awareness of their own fatherlands (маленкая родина), which would eventually bring them closer to the Russian motherland (большая родина). In other words, minorities should not be simply incorporated into the Russian Empire, but they should become more knowledgeable of their own histories and heritage. The appreciation of the ethno-cultural particularities in their

133 Referring to the disciples of Viktor Romanivich Rozen (1864-1908), Professor of Arabic at the Faculty of Oriental Languages at St. Petersburg University: Vasilii V. Bartold (1869-1930), Nikolai Ia. Marr (1864-1934), Sergei F. Oldenburg (1863-1934) and Fedor I. Shcherbatskoi (1866-1942); see Tolz (2011, pp. 13-19). 
native homelands would make them more loyal towards pan-Russian concerns and bring them into a better position to contribute to pan-Russian activities.

The proposed policy of citizen-building under Tsar Alexander II was to be achieved through political and spiritual fusion, being built on common, state-derived (Russian) civic norms and shared between Russians and indigenous people. This process of learning from indigenous people about their cosmopolitan heritage gained a huge body of systematic and factual ethnographic knowledge acquired about an East that was approached as neither enchanted nor threatening, but simply as an area of systematic scholarly research. However, these scholars also encountered a problem. It lay not in any lack of willpower among the indigenous people to cooperate, but rather in the lack of any interest shown by the Tsarist politicians who disregarded the knowledge mined in Russia's new Orient. Yet, it still had a great impact on the period during which it was articulated in Late Imperial Russia, as it was appreciated by Russian artists who delighted in oriental otherness. Similarly to trends prevailing at the time in Western Europe, Russian artistic creativity reflects a fascination with the country's Oriental lands, that was captured by a remarkable artistic upsurge during the Russian Silver Age. Driven by the spirit of rediscovering indigenous culture and a search for inspiration, artist-experts, illustrators and photographers were dispatched on expeditions and discovery tours to the Empire's remote areas both in the East and in the West.

The best-known example of this ethnographic inquiry is El Lissitzky's expedition of 1915-1916 to Jewish heritage sites along the Dnepr River, sponsored by the Jewish Ethnographic Society in St. Petersburg. A second example is Baron Guenzburg's ethnographic expedition to the Jewish Pale of Settlement supervised by An-Sky in 19111914. Driven by the spirit of rediscovering indigenous culture, similar expeditions established themselves within the Russian artistic milieu. Depending on their instigators, expeditions enjoyed either private or state sponsorship. Some of them were documented in glamorous art editions, lavishly decorated with sketches, paintings and photographs. These inspired members of the Russian avant-garde. For example, Gontcharova, Larionov, Malevitch and Tatlin were all affected by the recognition and analysis of "primitive art", such as icons, painted trays, lubok (coloured woodcut) and vyveska (sign-boards). It was this orientation toward primitivism, together with abstract forms of expression that shaped the Russian avant-garde art. As mentioned in the first part of this article, a fascination with the East is particularly obvious in the oeuvre of the St. Petersburg-based World of Art group that shaped Ballets Russes productions on the Paris stage.

This stage came to be the first platform for Russian artists to demonstrate to an audience abroad that a successful transfer of knowledge had happened between Russia's metropolis and her recently acquired Muslim lands. While the recommendations of imperial Orientalist scholarship were followed up only much later by the Nationalities Policy of the new Bolshevik elites, the dormant knowledge obtained during the last third of the nineteenth century about Russia's new subjects inspired 
Russian artists and initiated among them a mental move to, and incorporation of, Asia. On the one hand, their celebration of oriental counter-spaces on the stages of Western Europe and the Americas thus provided evidence that someone had made use of the observations foreseen for the project of citizen-building by the Tsarist government, although they had rehearsed abroad something that was indeed foreseen to be rehearsed at home: a renewed identity construct resulting from the expansionist policy of Imperial Russia, following her annexation of Turkestan. On the other hand, this celebration can also be seen as a self-fulfilling prophecy, as it redeemed a resolution proclaimed almost one hundred years earlier with regard to Russia's interest in her oriental periphery, in particular Bukhara, the former backbone of the ancient Silk Route, as the city that the Russians considered its most important economic and political stronghold. As early as in 1820, a Russian envoy ${ }^{134}$ had pinpointed the heralding mission which Russia had taken on for herself, with the aim of contributing to both popular enlightenment and scholarship in the countries of Western Europe:

\begin{abstract}
The fact that Russia has, for more than a century, been in touch with Bukhara, Khiva and Tashkent has made foreigners demand from us information about these cities, and rightly so. They require comprehensive knowledge from us separating solid facts from rumours, ... interesting news about the mores of the lands [нравах земел]. This is why we have to do our best to enlighten our fellow citizens about the historical and geographical facts in this part of the world. Who - if not us Russians - would inform European scholarship about present-day Bukhara. (Iakovlev, 1824 pp. 50-52)
\end{abstract}

As it turned out, the Ballets Russes became the facilitators of this heralding mission when they incorporated the knowledge gained by imperial ethnographers. A proposed policy of indigenization that had set out to learn from and teach the indigenous people resulted in observations about an oriental counter-space. These observations were now transformed into the subject of appreciation and worship by audiences in Paris, and later on London and other Western cities. The culture of admiration they sowed abroad still saw Russia as an exotic entity, outside Europe, while the legacy of Russian Orientalist scholarship has yet to be fully appreciated.

\title{
6.5 Conclusions
}

In conclusion, I have deconstructed the symbolic practices displayed by the dancers and decorators of the Ballets Russes and related them a) to the oeuvre of artist-animators in the St. Petersburg-based Mir Iskusstva group that had outsourced themselves to Paris, and b) to the process of the transfer of knowledge initiated by Russian

134 Iakovlev, a member of the Russian Embassy produced the first map of the city for Bukhara (as cited in Khanykov, 1848). 
Orientalist scholars in the last third of the nineteenth century between Russia's Western Christian centre and the Muslim-dominated areas of her Southern periphery. By having recourse to Foucault's "Theory of Other Spaces", with its focus on the formal, spatial qualities of certain places that may appear as "both mythical and real", I have demonstrated that the scenic counter-spaces which were revealed on stage to Western audiences served Russian artists as an outlet for their own protest against the decline in funding by royal patronage. Subsequently, it became their first platform to rehearse abroad a revamped identity, in which the unconditional pre-eminence of European culture broadcast by Tsar Peter I, was increasingly contested by Russia's Asiatic counterparts and her mental shift towards Asia.

Spaces of otherness and desire-spaces outside the ordinary, being of oriental otherness in particular-have been part of European imagery ever since modern transportation improved access to the Orient. In contrast with the legends of ancient times, in which the discovery of a talisman or the incantation of a magical formula assisted the hero's quest to gain entry to the Other's treasure house, modern travellers required a particular body of knowledge for their act of unlocking. Whether the acquisition of this extended body of knowledge can be interpreted as an act of colonialism is questionable, as it differs from Edward Said's (1978) idea of Orientalist scholarship as it was carried out in the service of the empire. Whereas Said's (1978) focus on the maritime expansion of Britain and France suggests that the extended body of knowledge about the Orient signified a form of imperial control used to subjugate the Other (p. XIV), the approach to citizen-building recommended by Russian ethnographers demonstrates that the acquisition and transfer of knowledge across a continental bridge could also be a pragmatic act of cooperation, in which the will to understand (p. XIV) and to communicate was considered a prerequisite for dialogue, appreciation, academic reorientation and joint action (Holly, 1987).

Accordingly, the Ballets Russes productions could be thought of as stages in a mindful, disciplined and regulated process of confrontation between acquired and imagined knowledge about the Oriental Other that has been taking place since the eighteenth century, as Said (1978) pointed out with regard to the maritime colonial powers (p. 3). While the spatial ambiguities displayed by the Ballets Russes were to an extent recognizable to Western audiences, the Oriental Other was appreciated as an allegory, in the sense that they demonstrated a truth or moral by using symbolism. The Ballets Russes' masters of enchantment indeed applied such symbolism, as was conveyed by stories and visual images, with a level of impact on Europe that they could hardly have imagined when they rehearsed in Paris a revamped identity sourced from a newly discovered treasure house in Asia, rather than from the familiar fairy-tale forests of Europe. It was the charm of this contrast that inspired the noticeable shift in empathy, understanding and desire that characterized this chapter in European Modernism. 


\section{References}

Auclair, M. (2009, November 24-2010, May 23). Introduction to the Exhibition Les Ballets Russes, BnF. Bibliothèque-musée de l'Opéra, Paris.

https://www.artistikrezo.com/agenda/exposition-qles-ballets-russesq-au-palais-garnier.html

Bakst, L. (1909). The Paths of Classicism in Art. Apollon 3 (December 1909) 46-61. Retrieved from http://www.v-ivanov.it/apollon/apollon_03_1909.pdf

Bassin, M. (1991). Russia between Europe and Asia: The Ideological Construction of Geographical Space. Slavic Review, 50(1), 1-17.

Benois, A. (1910, July 18). Khudozhestvennye pis'ma: russkie spektakli v Parizhe: Zhar ptitsa [Letters on art: Russian productions in Paris: The Firebird]. In Rech.

Birnbaum, M. (1916, December). Léon Bakst. America as Host to the Ballet Russes. Vogue (15), 15-25.

Bowlt, J. (1998). Theater of Reason/Theater of Desire. The Art of Alexandre Benois and Léon Bakst. Thyssen Bornemisza Foundation.

Bridgman, E. (1989). Mir Iskusstva Origins of the Ballets Russes. In: Nancy van Norman Baer (Ed.), The art of enchantment. Diaghilev's Ballets Russes, 1909-1929 (pp. 26-43). Universe Books,

Buckle, R. (1979). Diaghilev. Weidenfeld and Nicolson.

Diaghilev, Serge [1910]. (2009 November 24-2010 May 23). Information board at the exhibition Les Ballets russes, BnF. Bibliotèque-musée de l'Opéra, Paris.

Evans, E. (1933). Stravinsky. The Fire-Bird and Petrushka Humphrey Milford. Oxford University Press.

Ghéon, H. (1910, August). Propos divers sur le ballet russe. La Nouvelle Revue Française, 20, 199-212.

Foucault, M., \& Miskowiec, J. (1986). Of other spaces. Diacritics, 16(1), 22-27.

Holly, W. (1987). Sprachhandeln ohne Kooperation? Über den “kooperativen” Balanceakt beim Manipulieren. In: F. Liedtke \& R. M. Keller (Eds.), Kommunikation und Kooperation (pp. 137-157). Niemeyer.

lakovlev, P. (1824). Zamechaniia na fakty. Nekotorye svedeniia o Bukhare, napechatany v Otechesvennykh Zapiskakh $1821 \mathrm{~g}$. [Remarks about facts. Some evidence on Bukhara, printed in Otechesvennye Zapiski in 1821]. In: Sibirskii Vestnik (Vol. Ш, pp. 50-52). St. Petersburg.

Järvinen, H. (2008). The Russian Barnum: Russian Opinions on Diaghilev's Ballets Russes 1909-1914. In: Dance Research: The Journal of the Society for Dance Research (Vol. 1, pp. 18-41). Edinburgh University Press.

Jersild, A. L. (1997). From savagery to citizenship: Caucasian mountaineers and Muslims in the Russian empire. In: D. R. Brower \& E. Lazzerini (Eds.), Russia’s Orient (pp. 101-114). Indiana University Press.

Johnson, P. (2006). Unravelling Foucault’s ‘different spaces'. History of the Human Sciences, 19(4), 75-90.

Johnson, R. (1990). Bakst on Classicism: The Paths of Classicism in Art. Dance Chronicle, 13(2), $170-192$.

Kabbini, R. (1986). Europe's Myths of Orient. Palgrave Macmillan.

Kahane, M., \& Wild, N. (1922). Les Ballets Russes à l’Opéra. Hazan/Bilbiothéque Nationale.

Karpinski, C. (1963). Kashmir to Paisley. The Metropolitan Museum of Art Bulletin. New Series, 22(3), 116-123.

Kennedy, J. (1977). The Mir Iskusstva Group and Russian Art 1898-1912. Garland Publishing, Inc. Khanykov, N. D. (1848). Opisanie Bukharskogo Khanstva (The Description of the Bukhara Khanate) St. Petersburg.

Kiselev, M. (1989). Graphic Design and Russian Art. Journals of the Early Twentieth Century. The Journal of Decorative and Propaganda Arts, (Russian Soviet Theme), 11(3), 50-67. 
Komissarzhevskii, F. (1922). Russkoe iskusstvo v Londone. Tretie pis'mo iz Londona [Russian art in London. Third letter from London]. Teatr (Russian illustrated magazine issued in Berlin, 192-23), (14), 11.

Lancaster, 0. (1948). Home Sweet Home. J. Murray.

Levinson, A. (1924). Russkoe Iskusstvo v Evrope [Russian Art in Europe]. Zhar ptitsa (Berlin), (12), 9-14.

Lukomskii, G. (1922, February). Itogi i zadachi russkoi khudozhestvennoi deiatelnosti zagranitsei (1919-1921) [Achievements and tasks of the artists in Russia Abroad]. Novaia Russkaia Kniga (Berlin), (2), 3-4.

Marten-Finnis, S. (2012). Der Feuervogel als Kunstzeitschrift. Žar ptica. Russische Bildwelten in Berlin (1921-1926). Böhlau.

Marten-Finnis, S. (2013). The Return of Léon Bakst. Slav Magic or Oriental Other. Journal of Modern Jewish Studies, 12(2), 276-296.

Misler, N. (1989). Siamese Dancing and the Ballets Russes. In: Nancy van Norman Baer (Ed.), The art of enchantment. Diaghilev's Ballets Russes, 1909-1929 (pp. 78-83). Universe Books.

Moussinac, L. (1922). La Decoration Théatrale. F. Rieder et Cie.

Nance, S. (2009). How the Arabian Nights inspired the American Dream, 1795-1935. The University of North Carolina Press.

Raev, A. (2018). Weltenwechsel. Der Deutsch-Russische Maler Georg Schlicht (1886-1964) zwischen Saratow und Eisenach. In: Catalogue of the exhibition on Georg Schlicht, Georg-SchlichtStiftung.

Riasanovsky, N. (1967). The emergence of Eurasianism. In: California Slavic Studies (Vol. 4, pp. 44-45).

Said, E. (1978). Orientalism. Pantheon Books.

Schimmelpenninck Van Der Oye, D. (2010). Russian Orientalism. Asia in the Russian Mind from Peter the Great to the Emigration. Yale University Press.

Schouvaloff, A. (1997). The art of Ballets Russes. The Serge Lifar Collection of theater designs, costumes, and paintings at the Wadsworth Atheneum. Yale University Press.

Shestakov, V. (1998). Iskusstvo i mir v ,Mire iskusstva' [Art and World in ,World of Art']. Slavianskii Dialog.

Spencer, C. (1993, May). Erotic Dreams. In Antique Collector (pp. 66-71).

Taruskin, R. (1996). Stravinsky and the Russian Tradition. A Biography of the Works Through Mavra: Vol. I. Oxford University Press.

Taube, J. (1994). Suzani. A Textile Art from Central Asia. With an Introduction and Text to the Collection by Ignazio Vok. Munich: Edition Vok.

Diaghilev Festival Les Saisons Russes XXI (Ed.). (2011, April 12-17). Program Thamar (at London Coliseum), p. 14. Copy in possession of author.

Tolz, V. (2005). Orientalism, Nationalism and Ethnic Diversity in Late Imperial Russia. The Historical Journal, 48(1), 127-150.

Tolz, V. (2011). Russia's Own Orient. The Politics of Identity and Oriental Studies in the Late Imperial and Early Soviet Periods. Oxford University Press.

Usbekische Märchen. (1978). Edited. and translated by K. Reichl. Studienverlag.

Woodcock, S. (2009). The evidence of the backcloth. In A. Purvis, P. Rand \& A. Winestein (Eds.), The Ballets Russes and the Art of Design (pp. 55-62). The Monacelli Press.

Woodcock, S. (2010). Wardrobe. In J. Pritchard \& G. Marsh (Eds.), Diaghilev and the Golden Age of the Ballets Russes, 1909-1929. V\&A Publishing.

Zum Geleit [Introductory remarks]. In: Zhar Ptitsa no. 1 (August 1921).

Yaroshevski, D. (1997). Empire and citizenship. In D. R. Brower \& E. Lazzerini (Eds.) Russia’s Orient (pp. 58-79). Indiana University Press. 